\title{
THE OMISSIONS IN OPPELT
}

\author{
Duard Kleyn* \\ Emile Zitzke**
}

\section{ABSTRACT}

In this article, we explore the relationship between the legal historical method and the constitutionally transformative approach to the study of the South African private law. For this purpose, we provide an analysis of the decision in Oppelt $v$ Head: Health, Department of Health Provincial Administration: Western Cape 2016 (1) SA 325 (CC). In that case the claimant suffered a spinal injury during a rugby match and claimed damages on the basis of various omissions of medical professionals who failed to treat him timeously. These omissions lead to the claimant becoming quadriplegic. A legal historical analysis is conducted on the Aquilian liability for omissions and how the law related to omissions has developed in modern South African law. Thereafter the transformative constitutional approach to the South African private law - and more specifically the South African law of delict - is taken up. We conclude by considering the omissions in the Oppelt case, not only in the sense of conduct, but also in the sense that the Supreme Court of Appeal omitted to consider relevant constitutional considerations and the Constitutional Court omitted to thoroughly grapple with the common-law principles related to the case.

Keywords: Delict; omissions; wrongfulness; legal historical method; transformative approach to private law

* Professor Emeritus, Department of Jurisprudence, University of Pretoria. This article is a revised and extended version of a contribution that is forthcoming in Johan Scott: Ars Docendi et Scribendi, Essays in Honour of TJ Scott (2017) 11. In that contribution, the prescribed word limit did not allow for some ideas to be properly developed. The editors of that Festschrift have graciously allowed us to submit this article for review to Fundamina for purposes of peer review and accredited publication.

** Senior Lecturer, School of Law, University of the Witwatersrand. 


\section{Introduction}

In this article we wish to honour Professor Johan Scott who recently retired from the Department of Private Law at the University of Pretoria's Faculty of Law. Duard Kleyn is one of Professor Scott's earlier doctoral candidates who conducted an analysis of the place and purpose of the mandament van spolie in South African law from an historical perspective. ${ }^{1}$ Emile Zitzke is Professor Scott's last doctoral candidate at the University of Pretoria who investigated the interplay between the South African Constitution and the law of delict. ${ }^{2}$ The historical method and, since democratisation, constitutional approaches to South African private law have formed a substantial part of Professor Scott's research interest. ${ }^{3}$ In this piece we hope to show that the possibility might exist for an amalgamation of these two approaches to the study of South African law. We shall illustrate this possibility by conducting an analysis of the decision in Oppelt v Head: Health, Department of Health Provincial Administration: Western Cape. ${ }^{4}$

In that matter the seventeen-year-old claimant suffered serious low-velocity spinal injury during a rugby game. He was taken to Westfleur Hospital within the hour. At Westfleur, the attending doctor followed a hospital protocol which required that patients had to be referred to Groote Schuur Hospital before they could be sent to the special spinal-injury unit at Conradie Hospital. Mr Oppelt arrived at Groote Schuur more than two hours after the injury had occurred. At Groote Schuur the attending doctors referred him to the spinal-injury unit at Conradie where he had arrived by ambulance nearly twelve hours after the injury had been sustained. He underwent treatment at Conradie Hospital more than twelve hours after the injury. The victim alleged that the attending doctors at the various hospitals had omitted to provide punctual and apposite medical treatment to him, resulting in quadriplegia. The legal history and the constitutional implications of the doctors' omissions which caused the victim patrimonial harm is our focus in this article.

Our discussion is premised on four assumptions. Firstly, that the lex Aquilia forms the foundation of the rules of the South African law of delict that relates to the determination of liability for the causing of patrimonial harm. ${ }^{5}$ Secondly, that it is the implication of the Constitutional Court's judgment in the seminal case of Carmichele $v$ Minister of Safety and Security ${ }^{6}$ that a proper understanding of the

1 Kleyn 1986. Regarding the historical method in South African law see, eg, Van Zyl 1972; Van Zyl 1979: 3-4.

2 Zitzke 2016. Regarding the importance of a constitutional approach to the South African common law see, eg, Davis \& Klare 2010.

3 See, eg, Scott 1976 compared to Scott 2011, Scott 2012, Scott 2013 and Scott 2015.

42016 (1) SA 325 (CC).

5 See, eg, Zimmermann 1990: 921 \& 960; Loubser \& Midgley 2012: 27; Neethling \& Potgieter 2015: 8-12.

$62001(4)$ SA 938 (CC) at par 55. 
common-law position on a specific issue is necessary in order to decide whether and how to develop the common law. Thirdly, that Carmichele also stipulates that it is both desirable and necessary for the common law to be developed along constitutional lines to secure, albeit to a limited extent, the transformation of the common law. ${ }^{7}$ Fourthly, the implication of the first three assumptions is that both the historical and transformative approaches to private-law research should work in tandem with, rather than in opposition to, each other.

Therefore, in section 2 a brief historical overview of the law relating to omissions in the context of the law of Aquilian liability will be provided. Section 3 will then concisely consider the impact that the Constitution had in the determination of liability for omissions with specific reference to the Oppelt cases. Thereafter section 4 will provide some tentative thoughts on the importance of integrating the historical and constitutional methods for the flourishing of the South African common law.

\section{Historical background: The lex Aquilia}

\section{General}

Ulpian $^{8}$ tells us that the lex Aquilia is a plebiscite that was passed by the assembly of the plebs (the concilium plebis) and that it was proposed by a tribunus plebis called Aquilius. It is unknown who Aquilius was or when he lived. ${ }^{9}$ Ulpian ${ }^{10}$ also points out that the lex Aquilia "derogavit" all earlier laws as well as those contained in the Twelve Tables dealing with unlawful damage and that it is not necessary to refer to those laws any more. There is some controversy as to what exactly Ulpian meant with "derogavit" and it is suggested that to read it as "repealed", in the strict sense of the word, might be misleading as it seems that some of the earlier laws still remained. ${ }^{11}$ This, however, does not detract from the significance of the lex Aquilia. Given the impact of the lex Aquilia, a vexing question has always concerned the dating of the Act. Although this issue remains uncertain, the majority opinion favours the year 287 BC. ${ }^{12}$

The lex Aquilia was not a lengthy or complicated piece of legislation. It consisted of three chapters, ${ }^{13}$ which would today rather be viewed as paragraphs.

$7 \quad$ Carmichele at par 54.

8 D 9211.

9 Voet 921.

10 D $921 p r$.

11 See Voet 922 who refers to D 4771 where Paul and Labeo refer to the old law of cutting down trees by stealth that is still in force. Zimmermann 1990: 953 mentions "repealed and superseded". See, also, Van den Heever 1944: 15-20; Lawson 1950: 4-6; De Zulueta 1953: 209; Buckland 1966: 585; Du Plessis 2010: 319.

12 This opinion is often based on the last secession of the plebs and the adoption of the lex Hortensia in $287 \mathrm{BC}$ which made plebiscites binding on the whole Roman population, plebs and patricians alike. See Zimmermann 1990: 955; Lawson 1950: 4; Thomas 1975: 227; Van den Heever 1944: 7. See Inst 43 for a brief overview and Voet 924 . 
For our purposes, chapters one and three are of importance and will be discussed below. Their content has been preserved by Gaius and Ulpian. Chapter two (which concerned the adstipulator) had fallen into disuse in classical Roman law. ${ }^{14}$

There are many interesting issues in respect of the lex Aquilia, for example the calculation of the penalty or amount of damages, but the focus in this section will be on the nature of the human conduct (direct, indirect and omissions) as well as the corresponding legal remedies. The original version of the lex Aquilia did not provide a general act that covered all forms of unlawful damage. Its scope was quite narrow. Therefore, it was extended over the years by the praetor, the jurists and legislation, as will become clear from the discussion below.

\section{Chapter 1 of the lex Aquilia}

In his Institutes, Gaius provides us with the content of the first chapter of the lex Aquilia. If someone unlawfully kills (occidere) another's slave or four-footed animal of the class of cattle (pecus), he will be condemned to pay the owner the highest value thereof in that year. ${ }^{15}$ This account of Gaius was taken over in Justinian's Digest ${ }^{16}$ and Institutes. ${ }^{17}$ Pecus denote grazing animals which are kept in herds such as sheep, goats, horses, mules and, according to Labeo, also pigs (thus, farm animals). Later elephants and camels were also included. Dogs and wild beasts such as bears, lions and panthers do not fall within the category of pecus. ${ }^{18}$ It is clear, as De Zulueta points out, that chapter one "is limited in primitive style to a particular kind of injury done to particular kinds of property". ${ }^{19}$

In the original version of the lex Aquilia, occidere denoted direct conduct or physical action..$^{20}$ Gaius explains it as damage done with one's own body (corpore suo). ${ }^{21}$ This approach is also followed in Justinian's Institutes..$^{22}$ In the Digest it is mentioned that there will be liability for occidere only if the death resulted as it were by one's own hand (quasi manu) ${ }^{23}$ Direct conduct is also explained as damage by the body to the body, or rather to a thing (corpore corpori). ${ }^{24}$

14 D 9227 4; Inst 43 12. Regarding the second chapter of the lex Aquilia, see Zimmermann 1990: 954 and Lawson 1950: 6-7, the latter who regards this whole matter as obscure. See, also, Van den Heever 1944: 4-5.

15 G 3 210: "Damni iniuriae actio constituitur per legem Aquiliam, cuius primo capite cautum est (ut), si quis hominem alienum alienamue quadrupedem quae pecudum numero sit iniuria occiderit, quanti ea res in eo anno plurimi fuit, tantum domino dare damnetur."

$16 \mathrm{D} 922 \mathrm{pr}$.

17 Inst $43 p r$.

18 D 922 2; Inst 431.

19 De Zulueta 1952: 210. See, also, Van Warmelo 1971: 335.

20 Kaser 1971: 620.

$21 \quad$ G 3219.

22 Inst 4316.

23 D $9251 \mathrm{pr}$.

24 Kaser 1971: 620; Buckland 1966: 589; Van Warmelo 1971: 337; Van Zyl 1977: 340. 
The Digest provides us with some examples of causing death directly, for example hitting the victim with a sword or stick or another weapon or kicking with the foot; ${ }^{25}$ when someone throws another off a bridge and the victim is killed by the impact or drowns; ${ }^{26}$ or when a doctor operates negligently on a slave. ${ }^{27}$ Also if a midwife administers a drug with her own hands from which the woman dies ${ }^{28}$ or if someone administers a drug by force or persuasion in a drink or by injection. ${ }^{29}$

In all of the above cases the remedy is the direct Aquilian action, the actio legis Aquiliae. However, it seems that during the first century AD chapter 1 started to be extended, ${ }^{30}$ and liability was also recognised where death was not caused corpore suo but where the assailant still furnished the cause of death. The jurists referred to this indirect form of conduct as causam mortis praestare ${ }^{31}$ or mortis causam praebere. ${ }^{32}$ Celsus $^{33}$ says that it matters a great deal whether death was caused by occidere or mortis causam praestare because in the latter case the actio legis Aquiliae does not apply. For indirect conduct the praetor granted actiones utiles or actiones in factum. ${ }^{34}$

Gaius mentions that actiones utiles are granted in cases where one locks up another's slave or pecus and starves them to death; or drives another's beast so hard that it perishes; or persuades another's slave to climb a tree or go down a well and he falls and is killed. ${ }^{35}$ The same examples are mentioned in Justinian's Institutes ${ }^{36}$ but there it is pointed out that if neither the direct action nor the actio utilis will lie, the actio in factum can be awarded. Another example is the case where a midwife gives a drug to a woman who takes it herself, then an actio in factum is granted.$^{37}$ Likewise when someone scares the horse which another's slave is riding so that the horse throws the slave into the river and he dies, an actio in factum is granted ${ }^{38}$ also when someone holds a slave while another kills him the actio in factum will be granted against the one who held the slave,$^{39}$ or against the person who drives someone else's oxen over a precipice. ${ }^{40}$

D 9271 .

D 9277 .

D 9278 .

D $929 p r$.

D 9291 .

30 Lawson 1950: 22-23.

31 Ulpian D $929 p r$.

32 Ulpian D 92111.

33 D 9276.

34 Kaser 1971: 621.

35 G 3219.

36 Inst 4316.

37 D $929 p r$.

38 D 9293.

39 D 92111.

40 D 9253. 


\section{Chapter 3 of the lex Aquilia}

Ulpian provides a brief summary of the content of chapter three. ${ }^{41}$ In all other cases apart from the killing of a slave or pecus, if anyone does damage to another by wrongfully burning (urere), breaking (frangere) or destroying (rumpere) property, he must be condemned to pay to the owner whatever the property was worth in the most recent thirty days. Gaius explains that it implies that an action is provided under this chapter if a slave or pecus is wounded or if a dog or wild beast is killed or wounded which cases are not covered by chapter $1 .^{42}$ Ulpian furthermore remarks that all the early jurists (omnes veteres) understood rumpere to mean corrumpere (spoil) ${ }^{43}$ and he refers to Celsus who was of the opinion that corrumpere therefore included breaking and burning. ${ }^{44}$ Gaius ${ }^{45}$ says that corrumpere implies damage in any way for example also cutting, bruising, spilling et cetera. Zimmerman ${ }^{46}$ therefore, concludes that the interpretation of rumpere as corrumpere rendered "the other words contained in chapter three, 'urere' and 'frangere' somewhat redundant". Hence chapter 3 was more advanced and elastic in comparison to chapter 1 which was quite rigid. ${ }^{47}$

As was the case in chapter 1, it is assumed that under chapter 3 only direct physical human conduct was initially required to establish liability, similar to Gaius' corpore suo requirement. ${ }^{48}$ In these cases the direct action under the lex Aquilia, the actio legis Aquiliae was granted. The Digest furnishes us with the following examples: To singe a slave with a lighted torch; ${ }^{49}$ to burn down an orchard or a house, ${ }^{50}$. to burn down a block of flats; ${ }^{51}$ to pour wine away or spoil it; ${ }^{52}$ to tear or stain clothes; ${ }^{53}$ to pour someone else's millet or corn in a river; $;{ }^{54}$ to strike a slave or a mare who then suffers a miscarriage, ${ }^{55}$ to overload a mule so that parts of its body are fractured, ${ }^{56}$ and to sink a merchant ship. ${ }^{57}$

41 D 9227 5. "Tertio autem capite ait eadem lex Aquilia: 'Ceterarum rerum praeter hominem et pecudem occisos si quis alteri damnum faxit, quod usserit fregerit ruperit iniuria, quanti ea res erit in diebus triginta proximis, tantum aes domino dare damnas esto'." See, also, G 3217 and 218; Inst 4313 .

42 G 3 217; see, also, Inst 4313.

43 D 922713.

44 D 9227 16. De Zulueta 1952: 212 suggests that this interpretation of rumpere was settled well before the end of the Republic.

45 G 3217.

46 Zimmermann 1990: 985.

47 De Zulueta 1952: 210.

48 Kaser 1971: 620; Zimmermann 1990: 983.

49 D 92276.

$50 \quad$ D 92277.

51 D 92278.

52 D 922715 .

53 D 922718 .

54 D 922719.

55 D 922722 .

56 D 922723.

57 D 922724 . 
Later the indirect conduct was also recognised to give rise to liability under chapter 3 and in such cases an actio utilis or in factum was granted. If one man lighted a furnace and another watched over it carelessly so that the house burns down, the actio utilis lies against him who watched over it carelessly. ${ }^{58}$ When someone has an oven against a party wall and the wall burns down, the actio in factum will apply. ${ }^{59}$ If someone sows weeds or wild oats in another's crops and spoils them, the actio in factum under the lex Aquilia will apply. ${ }^{60}$ When someone damages my aqueduct, therefore my materials, because I do not lead the water over my land, an actio utilis should be granted. ${ }^{61}$ If someone cuts a ship's mooring rope and the ship is consequently lost, an actio in factum applies. ${ }^{62}$ If a municipal magistrate seizes someone's cattle as security and then starves them to death by not allowing the owner to feed them, an actio in factum will be granted. ${ }^{63}$

\section{Damage to freemen}

The purpose of the lex Aquilia was to deal with the delict of wrongful damage to property (damnum iniuria datum) which included damage to slaves and inanimate things (res). It did not cover the injury of or damage to the body of a freeman. But, as Lawson $^{64}$ points out, a slave was a Janus-like character as a slave was a person and a thing, and although injuring a slave was covered by the lex Aquilia it also amounted to a personal injury. The position of the slave served as a bridge to the injuring of a freeman eventually being covered by the lex Aquilia. Just like an owner could recover damages for the injury of his slave, a paterfamilias could recover his loss of profits for his son's services when the son's eye was damaged. ${ }^{65}$ Finally, as Ulpian ${ }^{66}$ mentions, a freeman can recover for an injury to himself under the lex Aquilia with an actio utilis. He cannot use the direct action because a freeman is not deemed to be the owner of his own limbs. Du Plessis, ${ }^{67}$ remarks that "this appears to be a major departure from the original scope of the lex Aquilia" and that it is a post-classical development, possibly as late as Justinian.

In the preceding discussion of types of human conduct and corresponding remedies under the lex Aquilia, the distinction between the original direct conduct and the later recognition of indirect forms of conduct in classical law as well as

$58 \quad \mathrm{D} 92279$.

59 D 922710.

60 D 922714.

61 D 922732.

62 D 92295.

63 D 92297.

64 Lawson 1950: 21.

65 D $927 p r$.

66 D $9213 p r$.

67 Du Plessis 2010: 327. 
damage to a freeman were pointed out. It is clear that in the case of direct conduct, the direct action provided by the lex Aquilia (the actio legis Aquilia) was awarded. For indirect conduct and for the injuring of a freeman actiones utiles and in factum were awarded under the lex. These were praetorian actions ad exemplum legis Aquiliae. ${ }^{68}$ The difference between these two kinds of extended actions is not clear and the texts are not consistent in this regard. Gaius ${ }^{69}$ remarks that when the damage was done corpore suo the direct action lies, but when damage was done in other ways, the actio utilis is awarded. In Justinian's Institutes ${ }^{70}$ - as in Gaius' Institutes - the direct action for damage done corpore suo is mentioned, and the actio utilis for damage caused in other ways, but then also the action in factum is mentioned when the damage was not caused by the body to a thing - for example when someone releases another's slave from his bonds and the slave runs away. The Digest ${ }^{71}$ contains a general statement that in cases of damage not covered by the lex Aquilia, an actio in factum is awarded. Romanists mention that the difference between actiones utiles and in factum is vague but that it is rooted in the intricacies of the law of procedure, specifically with the transition from the legis actio procedure to the formula procedure. ${ }^{72}$

\section{The omissio}

In the sections above we encountered examples of direct and indirect conduct under chapters 1 and 3 of the lex Aquilia. We must now turn to the omission, which is an important issue for this contribution. Romanists are unanimous in their view that there existed no Aquilian liability in Roman law for a mere omission. ${ }^{73}$ Beinart ${ }^{74}$ also points out that the terms commissum or omissum are not used in the Digest texts.

When discussing human conduct under the lex Aquilia, some authors even refrain from using the term omissio (or omission). They only distinguish between direct conduct corpore corpori and other forms of conduct for which the supplementary actions were awarded. ${ }^{75}$ However, there are those who use the term omission, like Zimmerman, but he emphasises the fact that there was no liability for a mere omission; it had to be preceded by previous direct conduct. ${ }^{76}$ The examples he has in mind are where someone locks up another's slave or cattle and then starves them to death ${ }^{77}$ or takes a slave's clothes away and he then freezes to death, ${ }^{78}$ or the doctor

68 Kaser 1971: 503-505.

69 G 3219.

70 Inst 4316.

$71 \quad$ D 92331.

72 Kaser 1971: 621; Buckland 1966: 589; Lawson 1950: 24-27; Van den Heever 1944: 22.

73 Kaser 1971: 503; Kemp 1978: 121ff; Zimmermann 1990: 1043; Lawson 1950: 26; Beinart 1949: 141.

74 Beinart 1949: 143.

75 Buckland 1966: 589; Thomas 1975: 368; Du Plessis 2010: 327-328.

76 Zimmermann 1990: 979-980. See, also, Thomas 1975: 273; Van Zyl 1977: 393.

77 D 3 219; and see D 92297.

78 D 195141. 
who fails to provide postoperative care. ${ }^{79}$ But some authors consider these as types of indirect conduct. ${ }^{80}$

The focus will now shift to post-Roman developments. Since the reception of Roman law in Western Europe, the law in practice as regards damnum iniuria datum gradually diverted from the rigid constraints of the Roman lex Aquilia. This was brought about by the influence of canon law, Germanic law and the approach of the practitioners. ${ }^{81}$ This eventually prompted Christian Thomasius to write his Larva Legis Aquiliae Detracta Actioni de Damno Dato Receptae in Foris Germanorum (the abbreviated translation being "the mask of the lex Aquilia torn off") in the early eighteenth century in which he maintained that the action they used for damage done was as different from the Aquilian action as a bird from a four-footed beast. ${ }^{82}$ The law in practice departed from the dogmatic ballast of Roman times and did away with the distinctions between direct and indirect conduct, direct actions and actiones utiles and in factum. It was time for a new theoretical framework, a "mores hodiernae" which was provided by the natural lawyers. ${ }^{83}$ As part of this dogmatic approach, Hugo Grotius proclaimed in his De Iure Belli ac Pacis, eighty years before Thomasius's Larva, that any conduct, whether a commission or an omission that causes damage because of fault should be made good. ${ }^{84}$ This was the "principal and fundamental proposition" of the natural law of delict ${ }^{85}$ and based on the second of Ulpian's praecepta iuris "alterum non leadere" ${ }^{86}$

The stream of natural law of delict found its way into the modern codifications of law of the eighteenth and nineteenth centuries. Most important were articles 1382 and 1383 of the French Code Civil. These articles proclaimed that damage caused by any conduct gave rise to liability if there was fault. Lawson ${ }^{87}$ remarks that "[a]rticle 1382 which enunciates a general liability for fault, reads like a manifesto, and it is doubtless to its quality of simple inevitability that it has owed its remarkable extension throughout the world".

79 Inst 436.

80 Van Warmelo 1971: 338-339; Thomas 2000: 371.

81 Zimmermann 1990: 1031; Lawson 1950: 28.

82 Hewett 2000: par 1; Lawson 1950: 28.

83 Zimmermann 1990: 1031.

84 De Groot 1625: 2 17 1: "Maleficium hic appellamus culpam omnem, sive in faciendo, sive in non faciendo, pugnantem cum eo quod aut homines communiter, aut pro ratione certae qualitatis facere debent. Ex tali culpa obligatio naturaliter oritur, si damnum datum est, nempe ut id resarciatur."

85 See Zimmermann 1990: 1032 who also refers to the views of Samuel Puffendorf and Christian Thomasius in this regard.

86 D 11101 . See, also, Kleyn \& Van Niekerk 2014.

87 Lawson 1950: 29. Article 1382 of the French Code Civil (1804) reads as follows: Tout fait quelconque de L'homme qui cause à autrui un dommage, oblige celui par la faute duquel ilest arrive, à le réparer. See, also, art 2042 of the Italian Code Civile (1942). The German Civil Code or Bürgerliches Gesetzbuch (1900) deviates from the gist of the French Code, see, eg, Lawson 1950: 29. See, further, Kemp 1978: 558ff. 
Fault was always the basis of Aquilian liability. Zimmermann ${ }^{88}$ remarks that liability based on fault in the nineteenth century "acquired the status of an unquestionable axiomatic truth". But with the recognition of a mere omission giving rise to delictual liability, the issue of iniuria (unlawfulness) also became important. When must one act? Legal theory dictated that one must act when there is a duty on one to act and, when one culpably neglects that duty, delictual liability arises. The duty to act depends on perceptions of public policy, common sense and terms of modern conceptual thinking. ${ }^{89}$

But not all lawyers departed from the Roman approach to Aquilian liability. Voet in his Commentarius ad Pandectas (1734) did not subscribe to the idea of liability on account of a mere omission. He followed the traditional Roman law approach that liability for an omission can only arise when there was prior positive conduct, for instance where a doctor did an operation but then abandoned curative treatment or when one took a duty upon him, like looking after a fire, but did not fulfil it..$^{90}$ Voet had a great influence in South African law. However, not all RomanDutch lawyers shared Voet's views. Mattheus II, for instance, was of the opinion that both a commission and an omission could lead to liability. ${ }^{91}$

\section{The lex Aquilia and omissions in South African law leading up to Oppelt}

In the early twentieth century South African judges in the Appellate Division strictly observed the prior-conduct rule in the determination of the actionability of omissions. In Halliwell $v$ Johannesburg Municipality ${ }^{92}$ the municipality laid cobblestones in Johannesburg's city centre but failed to maintain those stones. When Mr Halliwell crossed the cobblestone path with his horse carriage on a Christmas morning, his horse stumbled on the poorly-maintained road and Mr Halliwell was sent, flying like Santa Clause, through the air. The court held that the municipality was liable for the failure to maintain the cobblestone road which lead to Mr Halliwell's injuries. This was explicitly done on the basis of the prior-conduct rule. This rule was also employed in the case of Silva's Fishing Corporation v Maweza, ${ }^{93}$ where the owner of a boat sent fishermen out to sea (the prior positive conduct) but when the boat stopped working, the owner did nothing to save the fishermen (the subsequent omission). The boat owner was held liable for his omission.

90 Voet 923 . Voet maintains that it would be too harsh for a person to be held liable on wrongdoing for the slightest fault of omission. See, further, Kemp 1978: 144.

91 De Criminibus (1644) Ad Lib XLVIII Tit V Caput 6, 5.

921912 AD 659.

931957 (2) SA 256 (A). 
The absolute prominence of the prior-conduct rule as the only ground on which liability for an omission could be established came to an end with the decision in Regal v African Superslate..$^{44}$ In the judgment of Steyn CJ, the Appellate Division noted that the prior-conduct rule was not the only basis on which an omission would be actionable. It was explained that one neighbour owes a legal duty to prevent harm to another neighbour stemming from the former's property, if it would be reasonable and practicable to do so. This ultimately stems from the idea that if one is in control of dangerous property, one would be held liable in delict for harm that flows from the failure to prevent the danger from materialising. For the first time, the Appellate Division noted that the prior-conduct rule and the rule related to the control of dangerous property are both grounds on which the wrongfulness of an omission can be established. Before this decision, the prior-conduct rule featured in academic commentaries under the heading of "conduct", meaning that the element of conduct would be missing in a delictual action if there was no prior conduct. In Regal it was made plain that the conduct element could be satisfied by simply showing the factual existence of an act or an omission. The wrongfulness of the omission was then established by means of the prior-conduct rule or the rule related to the control of dangerous property. The principle from Regal was later also applied in the case of Minister of Forestry v Quathlamba where a fire started on one property, the owner of that property failed to control or contain the fire, and the fire spread to a neighbouring property. ${ }^{95}$

A much more radical extension of the rules related to the wrongfulness of omissions featured in the seminal case of Minister van Polisie v Ewels. ${ }^{96}$ In that case police officers passively stood by and watched as a fellow police officer brutally assaulted a civilian. The question was whether the passive police officers acted wrongfully in their failure to put a stop to the assault. The Appellate Division referred to the above cases to explain that mere omissions are not regarded as wrongful. However, the wrongfulness of an omission could be shown by invoking the priorconduct rule and the control-of-dangerous-property rule. The court held that those two rules are just two of many factors to consider in determining the wrongfulness of omissions. On our own translation, the court laid down the following general principle for establishing the wrongfulness of omissions: ${ }^{97}$

It appears that the stage of development has been reached where an omission is regarded as wrongful conduct also when the circumstances of the case are of such a nature that the omission does not only attract moral outrage but also that the legal convictions of the community require that the omission should be regarded as wrongful and that the suffered harm ought to be compensated by the person who failed to act positively. To determine

$941963(1)$ SA $102(\mathrm{~A})$.

$951973(3)$ SA 69 (A).

961975 (3) SA 590 (A).

97 Ewels at 597. 
whether there is wrongfulness, it is, in a given case of an omission, thus not about the "negligence" of the bonus paterfamilias, but about the question whether, in light of all the facts, a legal duty existed to act reasonably.

This dictum laid the foundation for understanding wrongfulness as a mixture of considerations related to morality (perhaps a call to natural law), the legal convictions of the community (a concept explained more thoroughly below), the appropriateness of compensation as a remedy for given harm-causing conduct, and the existence or not of a legal duty to act reasonably. In Ewels, considerations that weighed in favour of a finding of wrongfulness of the omission of the passive policemen included the legal duty placed on the police to protect citizens from harm, the special relationship between police officers and the public, and the fact that the passive policemen were in a position to exercise authority or control over their assaultive colleague.

After Ewels, it could be said that a new era dawned for the South African law of wrongful omissions. Even though the older grounds for wrongful omissions were not eradicated, their "sole prominence" seemed to have faded for the most part. In the case of Cape Town Municipality v Bakkerud ${ }^{98}$ similar facts to those of Halliwell arose, but the court considered a multitude of factors (ultimately related to the imminence of the risk posed by a poorly maintained sidewalk) that could show that the legal convictions of the community required the imposition of a legal duty on the municipality. In the case of Administrateur Transvaal $v$ Van der Merwe, ${ }^{99}$ where the facts of Minister of Forestry were mimicked, the court considered the controlof-dangerous-property rule as only one factor to establish the wrongfulness of an omission. Other factors highlighted by the court include the balancing of interests of the wrongdoer, the victim and the community; the relationship between the disputing parties (presumably borrowed from Ewels); the social consequences of the conduct and holding the alleged wrongdoer liable in a case such as this; whether there were reasonably practical measures by which the harm could successfully be averted; and the cost of such measures. Clearly, it can be seen that the policy considerations taken into account in interrogating the wrongfulness of omissions is ever-expanding.

However, even the Supreme Court of Appeal is not always consistent in how it applies the multitude of factors for determining the wrongfulness of omissions. In the more recent decision of $Z a v$ Smith, ${ }^{100}$ a man visited a private game reserve and made his way up a mountain covered by snow. He ventured too far to the slope of the mountain and plummeted to his death. The question faced by the Supreme Court of Appeal was whether the owner of the game reserve's failure to prevent harm to $\mathrm{Mr} \mathrm{Za}$ was wrongful. The court ultimately disposed of the wrongfulness enquiry by quite simply relying on the old rule stating that a person in control of

982000 (3) SA 1049 (SCA).

991994 (4) SA 347 (A).

1002015 (4) SA 574 (SCA). 
potentially dangerous property owes a duty to others to prevent that harm from occurring. As such, the omission in this case was wrongful. Talk about other factors did not prominently feature in this judgment. Thus, it would seem that sometimes the wrongfulness of an omission could be established on a single factor that points in that direction, while in other cases, a more complex grappling with a variety of factors that must be weighed and balanced is employed.

The more complex, multi-layered approach to establishing the wrongfulness of omissions seems to have the approval of the Constitutional Court. After Ewels, the judgment that had the biggest influence on the law of wrongful omissions is the Constitutional Court's decision in Carmichele. In Carmichele, the claimant was attacked by a dangerous criminal with a horrendous track record of perpetrating gender-based violence. The problem was that the criminal appeared in court shortly before his attack on the claimant, where the prosecutor did not oppose his release pending the trial, despite the criminal's history. Thus, the prosecutor failed to bring relevant information before the court that probably would have secured his detention pending the trial. Furthermore, various members of the South African Police Service did not listen to the claimant's concerns that the criminal was roaming free on the streets of her neighbourhood and did not take steps to ensure his removal from a society filled with potential victims. After being unsuccessful in the lower courts, Ms Carmichele appealed to the Constitutional Court where the issue of wrongfulness dominated the Court's attention. The Carmichele judgment is important in many respects, but for current purposes, we simply draw attention to two aspects of the judgment that may be deduced from the following quotation on the enquiry into the wrongfulness of omissions: ${ }^{101}$

This is a proportionality exercise with liability depending upon the interplay of various factors. Proportionality is consistent with the Bill of Rights, but that exercise must now be carried out in accordance with the "spirit, purport and objects of the Bill of Rights" and the relevant factors must be weighed in the context of a constitutional state founded on dignity, equality and freedom and in which government has positive duties to promote and uphold such values.

The first striking aspect of this quotation is that the wrongfulness has to be understood in constitutional terms. As much, the Constitution gave content to the "legal convictions of the community" first expressed in the case of Ewels. In Carmichele's case, her constitutional rights and the corresponding constitutional obligations imposed on the state and its various functionaries were relevant considerations. These rights and duties are supported by international law. ${ }^{102}$ Secondly, the Constitutional Court alluded to the fact that the determination of wrongfulness is a balancing exercise

101 Carmichele at par 43.

102 Idem at par $47 \mathrm{ff}$. 
where competing considerations in favour of and against wrongfulness must be considered.

The multi-layered balancing exercise in the wrongfulness enquiry was most clearly communicated in later police-liability cases (the facts of which all involve some type of failure on the side of the police that leads to physical harm being suffered by innocent victims). In the case of Minister of Safety and Security $v$ Van Duivenboden, ${ }^{103}$ the Supreme Court of Appeal held that the wrongfulness enquiry involves weighing up factors in favour of a positive finding of wrongfulness and those factors that would resist a positive finding of wrongfulness. Factors in favour of wrongfulness in that case included the victim's constitutional rights that the state was under a duty to protect; statutory duties placed on the police to protect victims; and the constitutional norm of accountability that required an appropriate remedy to be given to victims of state malfeasance. However, contrariwise the Supreme Court of Appeal noted that the norm of accountability would not always require a privatelaw duty being placed on the state - if there were other effective remedies available to the victim, those remedies should be pursued before an award for damages in delict is sought; if the victims of state negligence constitute an indeterminate segment of society, a court would be less likely to find wrongfulness; and if the award for damages would impede the efficiency of government then a court would be less likely to establish wrongfulness.

Variations on this balancing exercise were observed in the cases of Van Eeden $v$ Minister of Safety \& Security (Women's Legal Trust Amicus Curiae); ${ }^{104}$ Minister Van Veiligheid en Sekuriteit v Geldenhuys; ${ }^{105}$ Minister of Safety and Security v Hamilton; ${ }^{106}$ Minister of Safety and Security $v$ Rudman; ${ }^{107}$ Minister of Safety and Security $v$ Venter ${ }^{108}$ and Mashongwa $v$ Passenger Rail Agency of South Africa. ${ }^{109}$ What becomes clear from these cases is that the "wrongfulness" of an omission is not simply determined with reference to whether a legal norm or rule has been breached. ${ }^{110}$

A different tune is apparently sung in the context of non-state wrongdoers. In Van Duivenboden, ${ }^{111}$ the Supreme Court of Appeal explicitly stated that state actors and non-state actors are not treated the same insofar as the determination of the wrongfulness of an omission is concerned:

1032002 (6) SA 431 (SCA).

104 Ibid.

1052004 (1) SA 515 (SCA).

1062004 (2) SA 216 (SCA).

1072005 (2) SA 16 (SCA).

1082011 (2) SACR 67 (SCA).

1092016 (3) SA 528 (CC).

110 See, in this regard, South African Hang and Paragliding Association v Bewick 20153 SA 449 (SCA).

111 Van Duivenboden at par 19 (footnotes omitted). 
The reluctance to impose liability for omissions is often informed by a laissez faire concept of liberty that recognizes that individuals are entitled to 'mind their own business' even when they might reasonably be expected to avert harm, and by the inequality of imposing liability on one person who fails to act when there are others who might equally be faulted. The protection that is afforded by the Bill of Rights to equality, and to personal freedom, and to privacy, might now bolster that inhibition against imposing legal duties on private citizens. However, those barriers are less formidable where the conduct of a public authority or a public functionary is in issue, for it is usually the very business of a public authority or functionary to serve the interests of others, and its duty to do so will differentiate it from others who similarly fail to act to avert harm.

The reluctance to impose positive duties on private actors can be seen in recent cases such as Tsogo Sun Holdings $v$ Qing-He Shan, ${ }^{112}$ where it was held that casinos (and by extension perhaps other public accommodations too) are under no obligation to scan patrons for dangerous weapons. As such, if a dangerous patron shoots another patron, the casino will not be held liable for its failure to check whether patrons are carrying guns upon their entry. A similar reluctance was recently shown in Stedall $v$ Aspeling ${ }^{113}$ where a child was severely injured on account of a property owner's failure to close gates leading to a swimming pool in which the child nearly drowned. The Supreme Court of Appeal held that the failure to secure the gates leading to the swimming pool was not wrongful and that the sole responsibility for the child's injury lay with the distracted parents who did not keep a continuous eye on the child. This is not an absolute reluctance though: As mentioned above, in $\mathrm{Za}$ a property owner was held liable for the failure to exercise care over their potentially dangerous property. Similarly, in Pro Tempo v Van der Merwe, ${ }^{114}$ it was held that a school acted wrongfully in its failure to prevent children with disabilities from playing in an area where steel rods had been planted in the ground next to trees. The child victim in that case sat on one of the steel rods and impaled himself thereon, resulting in serious bodily injury. The wrongfulness there appeared to have been established on the basis of control over a dangerous situation and perhaps the prior-conduct rule.

According to the modern delict canon in South African law, we still establish the wrongfulness of omissions primarily on the basis of certain crystallised manifestations of the legal convictions of the community, namely the "prior-conduct rule", "control of a dangerous situation", "statutory duty", "a special relationship between the parties", "holding a particular office" or a combination of those factors. ${ }^{115}$ In this canon, very little attention has been paid to the nuances between the wrongfulness of omissions of the state versus those of non-state actors and very little attention has

1122006 (6) SA 537 (SCA).

1132018 (2) SA 75 (SCA).

1142018 (1) SA 181 (SCA).

115 See, eg, McKerron 1971: 14ff; Boberg 1984: 33ff; Van der Merwe \& Olivier 1989: 20ff; Zimmermann 1990: 1046ff; Van der Walt \& Midgley 2005: 70ff; Neethling \& Potgieter 2015: $60 \mathrm{ff}$. 
also been paid to the balancing exercise promoted in the cases cited above. It will be seen below that these complexities have also not necessarily been understood by the various courts that had to grapple with the problem in Oppelt.

The developments canvassed here on the law relating to the wrongfulness of omissions are aptly summarised by Van der Westhuizen $\mathrm{J}$ in Loureiro $v$ iMvula Quality Protection: ${ }^{116}$

The wrongfulness enquiry focuses on the conduct and goes to whether the policy and legal convictions of the community, constitutionally understood, regard it as acceptable. It is based on the duty not to cause harm - indeed to respect rights - and questions the reasonableness of imposing liability.

It is against this backdrop that the decisions of the various courts in Oppelt should be understood. It is important to stress further that an omission would have to be "negligent" and the "factual and legal cause" of the "harm" suffered by the victim in order to be actionable. Wrongfulness is thus not the beginning and the end of a delictual dispute.

\section{The Constitution and omissions in Oppelt}

\section{Litigation history}

Mr Oppelt was successful in the High Court with his claim to hold the employer of the various doctors vicariously liable. ${ }^{117}$ However, a unanimous bench of the Supreme Court of Appeal overturned that decision mainly on account of its interpretation of the medical evidence presented at the trial which had a negative effect on the finding of factual causation. Two doctors testified about the medical consequences flowing from a failure to treat spinal injuries swiftly. On the one hand Dr Newton testified that his experience and academic research had shown that patients who receive treatment for spinal injuries within four hours of injury have a sixty four per cent chance of full recovery while those who are treated more than four hours after injury have virtually no prospect of recovery. ${ }^{118}$ On the other hand Dr Welsh testified that there was no consensus among medical professionals on Dr Newton's four-hour rule. ${ }^{119}$ The Supreme Court of Appeal held that Dr Newton's evidence was statistically unreliable, inaccurate and questionable, ${ }^{120}$ effectively telling the academic reviewers of Dr Newton's research that they did not know what they were doing - a peculiar

1162014 (3) SA 394 (CC) at par 53.

117 The Head: Health, Department of Health Provincial Administration: Western Cape v Oppelt 2014 ZASCA 135 at par 4.

118 Idem at paras 5-8 \& 10.

119 Idem at paras $9 \& 11-13$.

120 Idem at paras $18-20$. 
proclamation of scientific self-confidence on the part of the Supreme Court of Appeal. This finding meant that the victim had not proven on a balance of probabilities that the omissions of the doctors factually caused the victim's quadriplegia. ${ }^{121}$

Finally, the Supreme Court of Appeal briefly indicated that because there was no consensus in the medical profession on whether spinal injuries should be treated within four hours, neither wrongfulness (the existence of a legal duty borne by the doctors) nor negligence (reasonable foreseeability and preventability of harm) could be established. ${ }^{122}$ Consequently, the appeal was upheld. ${ }^{123}$

The Supreme Court of Appeal judgment is primarily problematic because of its approach to the evaluation of expert evidence, as critiqued by the Constitutional Court on appeal discussed below. But the judgment is also problematic from a theoretical and doctrinal perspective. Doctrinally the judgment creates the impression that one scientific fact could justify negative findings of factual causation, wrongfulness and negligence which are elements that have historically been regarded as fulfilling different functions with different considerations being relevant to the establishment of each. Theoretically, it is noted with concern that the Supreme Court of Appeal did not mention the Constitution even once in its judgment. The constitutional avoidance in this case is symptomatic of a chronic problem observed in recent judgments of the Supreme Court of Appeal which could be called "constitutional heedlessness" in terms of which a "business-as-usual" approach is applied to common-law problems while more serious constitutional engagement is in fact necessary. ${ }^{124}$ These problems have fortunately been resolved by the Constitutional Court on appeal.

\section{Oppelt in the Constitutional Court}

The majority of the Constitutional Court held that the Supreme Court of Appeal erred in at least two fundamental respects. Firstly, the Supreme Court of Appeal radically and unjustifiably departed from its earlier judgment in Michael $v$ Linksfield Park Clinic $^{125}$ with regard to the evaluation of expert evidence. The Constitutional Court in Oppelt noted that the Supreme Court of Appeal in Michael had held, among other things, that there is a difference between scientific and judicial measures of proof, and that an expert's testimony must show logical reasoning based on something more than professional intuition. ${ }^{126}$ Applied to the case at hand Dr Newton's fourhour rule was based on his own experience as a specialist practitioner, bolstered by the reviewed and published work of others, as well as an article that he authored that had been accepted for publication at the time of his testimony. Dr Welsh's testimony

121 Idem at paras 21-23.

122 Idem at paras 24-25.

123 Idem at paras 27-28.

124 Zitzke 2016: 22ff; Zitzke 2015: 259ff.

1252001 (3) SA 1188 (SCA).

126 Oppelt $C C$ at par 36. 
amounted to speculation because he provided no logical basis for his reasoning, unlike Dr Newton. ${ }^{127}$ The result of approving Dr Newton's testimony is that factual causation had now been established: If the doctors treated Mr Oppelt within four hours of sustaining the injury, the probability was that he would have made a full recovery. ${ }^{128}$

Secondly, and more importantly for purposes of the present discussion, the Supreme Court of Appeal fell into the trap of constitutional heedlessness in the determination of the wrongfulness of the doctors' conduct. While the Supreme Court of Appeal held that the doctors bore no legal duty towards Mr Oppelt for "scientific" reasons, the Constitutional Court reiterated its earlier definition of wrongfulness provided in Loureiro ${ }^{129}$ to the effect that the enquiry is centred around whether the alleged wrongdoer bore a legal duty not to cause harm and whether it would be reasonable to impose liability on the alleged wrongdoer - the criterion of reasonableness, which relates to the legal convictions of the community, has to be constitutionally construed. ${ }^{130}$

In this regard the Constitutional Court held that section 27(3) of the Constitution, stating that "[n]o one may be refused emergency medical treatment", was a relevant consideration in determining whether the doctors owed a legal duty towards $\mathrm{Mr}$ Oppelt. The legal convictions of the community, constitutionally understood, thus required doctors to provide patients with proficient medical care. This position is complimented by section $25(2)(\mathrm{m})$ of the National Health Act ${ }^{131}$ which enjoins the Health Department to provide and coordinate, among other things, emergency medical services. The purpose of the constitutional provision for emergency healthcare was described in Soobramoney v Minister of Health, Kwa-Zulu Natal ${ }^{132}$ as a safeguard against bureaucratic impediments standing between a person who has faced a medical catastrophe and immediate medical attention. ${ }^{133}$ The way in which section 27(3) was interpreted in Soobramoney provided the court with four criteria for determining whether the right to emergency medical care was breached: (1) There must be an emergency; (2) treatment must have been necessary; (3) the treatment must have been available: (4) and the treatment must have been refused. ${ }^{134}$

Applied to the facts in Oppelt, the Constitutional Court held that according to the hospitals' triage scales the victim required urgent medical intervention and thus there was an emergency. ${ }^{135}$ The treatment was necessary because the medical evidence

127 Idem at paras 37-48.

128 Idem at par 49.

129 See par 34.

130 Idem at par 51.

13161 of 2003.

1321998 (1) SA 765 (CC) par 20.

133 Oppelt $C C$ at par 55.

134 Idem at par 57.

135 Idem at par 58. 
presented showed that spinal injuries require treatment sooner rather than later. ${ }^{136}$ The treatment was held to be available because the Department of Health made no pleas relating to lack of resources. Furthermore, the closed reduction treatment for spinal injuries like the one that Mr Oppelt had is inexpensive and takes little time to administer especially when the equipment was available as it was in this case. No reasons were given why a helicopter had not been dispatched to transport $\mathrm{Mr}$ Oppelt even though the records showed that the helicopter had been available. ${ }^{137}$ Even though various doctors examined Mr Oppelt that does not mean that he had received emergency medical treatment. "Reasonable" and "appropriate" intervention was required. In other words, "refusal" does not simply mean that the patient is turned away at the hospital doors. Instead, the court applied a constructive test for "refusal" whereby tardy care, in the face of a need therefor and availability thereof, constitutes a denial of emergency treatment. ${ }^{138}$ Due to the breach of section 27(3) of the Constitution, the conduct of the doctors was held to be wrongful. ${ }^{139}$

Negligence was also held to be present. The classical test for negligence laid down in Kruger $v$ Coetzee ${ }^{140}$ requires a court to establish whether the reasonable person in the shoes of the alleged wrongdoer would, firstly, have reasonably foreseen the possibility of harm; secondly, would have taken reasonable steps to prevent the harm; and, thirdly, did not take those preventative steps. The Constitutional Court in Oppelt held that the reasonable-person criterion is raised to a higher standard of the reasonable medical practitioner in cases where the alleged wrongdoer has alleged to have a certain degree of care and skill. ${ }^{141}$ Here, a reasonable doctor would reasonably have foreseen the possibility of harm because it had been well known that spinal injuries required the promptest possible treatment (even if the four-hour rule was not generally accepted) and that the harm could reasonably have been averted if the doctors had made attempts to transfer the patient to Conradie Hospital directly from Westfleur, thus preventing a delay. ${ }^{142}$ Due to these facts, the doctors had been negligent. ${ }^{143}$ Thus, the appeal was upheld and Mr Oppelt was entitled to claim whatever damages he was able to prove. ${ }^{144}$

With regard to the law of delictual liability flowing from omissions, this judgment is to be welcomed in many respects with a few caveats that should nevertheless be raised. Contrary to the Supreme Court of Appeal, the Constitutional Court did not hold that one statement of scientific evidence could prove or disprove all the elements

136 Idem at paras 60-61.

137 Idem at par 62-65.

138 Idem at par 66.

139 Idem at par 68.

1401966 (2) SA 428 (A) 430E-G.

141 Idem at par 71.

142 Idem at par 79.

143 Idem at par 83.

144 Idem at par 86. 
of a delict. The Constitutional Court maintained clear doctrinal separation between the factors relevant in determining factual causation, wrongfulness and negligence respectively: For factual causation, (1) the four-hour rule promoted by Dr Newton was relevant; (2) for wrongfulness, the constitutional legal convictions of the community were important; and (3) negligence could be established with regard to the general foreseeability of harm that could flow from sluggish medical treatment, even though the reasonable doctor might not have had intimate knowledge of Dr Newton's new four-hour theory. Theoretically, this judgment also fits more comfortably in the transformative paradigm in that the Constitution was taken seriously by the court. An explicit and thorough constitutional analysis featured in the determination of wrongfulness, which is a great improvement from the judgment of the Supreme Court of Appeal. However, this judgment is also vulnerable to criticism.

Even though the court should be commended for the doctrinal respect shown to the elementology of delict, the court would have done better if it had conceded that the determination of wrongfulness is not solely a constitutional issue. The commonlaw description of wrongfulness certainly involves the legal convictions of the community and the establishment of a legal duty not to cause harm. However, as Neethling and Potgieter indicate, various flexible principles have arisen from case law as to when a legal duty not to cause harm arises. ${ }^{145}$ Some common-law criteria from the delict canon relevant to establishing the existence of a legal duty imposed on the doctors in Oppelt include the control of Mr Oppelt's "dangerous situation", ${ }^{146}$ a "special relationship" between the doctors and their patient, ${ }^{147}$ and perhaps the "breach of a rule of law" or "breach of a statutory (or constitutional) duty". ${ }^{148}$ Furthermore, we know from Carmichele, Van Duivenboden and subsequent state liability cases that the breach of a constitutional duty does not necessarily translate into private-law liability in delict. Consideration could have been given to the unavailability of alternative remedies, the fact that there is a determinate victim here, that the efficiency of government would not have been impeded by the imposition of a legal duty, and perhaps a conversation could have been had about why delictual liability should follow here even though the problem in this case ultimately arose from the implementation of a bad government policy.

Thus, in addition to the breach of section 27(3) of the Constitution, an interplay of traditional common-law factors also justified the finding of wrongfulness. To the extent that the court solely applied constitutional law to the determination of wrongfulness, it could be said to have acted "constitutionally over-excitedly" due to the fact that established common-law principles were effectively ignored and replaced by the Constitution. ${ }^{149}$ This type of excitement does not necessarily amount

145 Neethling \& Potgieter 2015: 55ff.

146 Idem 62-65.

147 Idem 69-71.

148 Idem 66-69 \& 78-79.

149 Zitzke 2015: 279. 
to a transformative approach to the common law. A truly transformative approach to common-law matters recognises a strong interplay between common law and Constitution so as to avoid the unnecessary monumentalisation of either source of law, while being mindful of the supremacy of the Constitution and the important role that it has to be play in rethinking South African law to keep abreast with the democratic needs of the people that it is meant to serve. ${ }^{150}$

\section{Conclusion}

The Oppelt case is about omissions. Not only omissions in the sense of conduct indeed, we also find the Supreme Court of Appeal's omission of the Constitution which poses a hurdle to the transformative aims of the supreme Constitution which places all law under the human-rights spotlight. Simultaneously the Constitutional Court's omission of properly considering the common-law principles relevant to the establishment of wrongfulness also inhibits the transformative project of the Constitution - it should be remembered that a "transformation" is situated somewhere in between a "revolution" and mere "reform". ${ }^{151}$ If the Constitution aimed to revolutionise South African law, it would have required a complete rewrite of all legislation, common law and customary law. However, the Constitution does not provide for such measures. ${ }^{152}$ Instead, it obliges us to reimagine the common law, where necessary, along constitutional lines. ${ }^{153}$ This does not mean that judges should sit back and allow the common law to stagnate in non-human-rights splendour. Rather, a midway between the two extremes of constitutional avoidance and constitutional over-excitement should be found. And it is our argument that at least one way of accomplishing this is by combining the historical and constitutional approaches to common-law analysis and that the two methods should be employed symbiotically rather than antagonistically.

\section{BIBLIOGRAPHY}

Beinart, Ben (1949) "Culpa in omittendo" J of Contemporary Roman-Dutch Law 12: 141-169

Boberg, PQR (1984) The Law of Delict (Cape Town)

Buckland, WW (1966) A Text-Book of Roman Law from Augustus to Justinian (Cambridge)

Davis, Dennis M \& Klare, Karl (2010) "Transformative constitutionalism and the common and customary law" South African J on Human Rights 26(3): 403-509

150 Idem 290.

151 Klare 1998: 150.

152 See, eg, s 39(3) and Schedule 6 of the Constitution which implies that old laws and rights remain in force, subject to constitutional compliance.

153 See, eg, ss 2, 8(2)-(3) \& 39(2) of the Constitution. 
De Groot, Hugo (1625) De Jure Belli ac Pacis (Amsterdam)

De Zulueta, Francis (1952) The Institutes of Gaius. Part II: Commentary (Oxford)

Du Plessis, Paul (2010) Borkowski's Textbook on Roman Law (Oxford / New York)

Hewett, Margaret (ed/trans) (2000) Larva Legis Aquiliae: The Mask of the Lex Aquilia Torn Off. The Action for Damage Done: A Legal Treatise by Christian Thomasius (Oxford)

Kaser, Max (1971) Das römische Privatrecht Erster Abschnitt (Münich)

Kemp, KJ (1978) Delictual Liability for Omissions (University of Port Elizabeth)

Klare, Karl (1998) "Legal culture and transformative constitutionalism" South African J on Human Rights 14: 146-188

Kleyn, Duard (1986) Die Mandament van Spolie in die Suid-Afrikaanse Reg (University of Pretoria)

Kleyn, Duard \& Van Niekerk, Gardiol (2014) “Ulpian's praecepta iuris and their role in South African law, part 1: Historical context” Fundamina 20(1): 437-445

Lawson, FH (1950) Negligence in the Civil Law: Introduction and Selected Texts (London)

Loubser, Max \& Midgley, Rob (eds) (2012) The Law of Delict in South Africa (Cape Town)

McKerron, RG (1971) The Law of Delict (Cape Town)

Neethling, J \& Potgieter, JM (2015) Neethling-Potgieter-Visser Law of Delict (Durban)

Scott, Johan (1976) Die Geskiedenis van die Oorerflikheid van Aksies op Grond van Onregmatige Daad in die Suid-Afrikaanse Reg (University of Leyden)

Scott, Johan (2011) "Effect of the destruction of a dwelling on the personal servitude of habitatio: Kidson v Kimspeed Enterprises CC 20095 SA 246 (GNP)" J of Contemporary RomanDutch Law 74: 155-169

Scott, Johan (2012) "Staatsaanspreeklikheid vir opsetsdelikte van die polisie - die Hoogste Hof van Appél kry nogmaals bloedneus: F v Minister of Safety and Security 20121 SA 546 (KH)" Journal for South African Law 2012(3): 541-558

Scott, Johan (2013) "Vicarious liability for intentional delicts - the constitutional factor clinches liability: Von Beneke v Minister of Defence 20125 SA 225 (GNP); Minister of Defence v Von Beneke (115/12) [2012] ZASCA 158" Journal for South African Law 2013(2): 348-361

Scott, Johan (2015) "Delictual liability for adultery: A healthy remedy's road to perdition" in Potgieter, J et al (ed) Essays in Honour of Johann Neethling (Durban) 421-438

Thomas, JAC (ed) (1975) The Institutes of Justinian Text Translation and Commentary (Amsterdam / Oxford)

Thomas, PhJ et al (2000) Historical Foundations of South African Private Law (Durban)

Van den Heever, FP (1944) Aquilian Damages in South African Law (Cape Town)

Van der Merwe, NJ \& Olivier PJJ Die Onregmatige Daad in die Suid-Afrikaanse Reg (Pretoria)

Van der Walt, JC \& Midgley JR (2005) Delict: Principles and Cases (Durban)

Van Warmelo, Paul (1971) 'n Inleiding tot die Studie van die Romeinse Reg (Cape Town)

Van Zyl, DH (1972) "Die regshistoriese metode" Journal of Contemporary Roman-Dutch Law 35: 19-37

Van Zyl, DH (1977) Geskiedenis en Beginsels van die Romeinse Privaatreg (Durban) 


\section{DUARD KLEYN AND EMILE ZITZKE}

Van Zyl, DH (1979) Geskiedenis van die Romeins-Hollandse Reg (Durban)

Zimmermann, Reinhard (1990) The Law of Obligations: Roman Foundations of the Civilian Tradition (Münich / Cape Town)

Zitzke, Emile (2015) "Constitutional heedlessness and over-excitement in the common law of delict's development" Constitutional Court Review 7: 257-290

Zitzke, Emile (2016) A New Proposed Constitutional Methodology for Effecting Transformation in the South African Law of Delict (University of Pretoria)

\section{Cases}

Administrateur, Transvaal v Van der Merwe 1994 (4) SA 347 (A)

Cape Town Municipality v Bakkerud 2000 (3) SA 1049 (SCA)

Carmichele v Minister of Safety and Security 2001 (4) SA 938 (CC)

Halliwell v Johannesburg Municipal Council 1912 AD 659

Kruger v Coetzee 1966 (2) SA 428 (A)

Loureiro v iMvula Quality Protection 2014 (3) SA 394 (CC)

Mashongwa v Passenger Rail Agency of South Africa 2016 (3) SA 528 (CC)

Michael v Linksfield Park Clinic 2001 (3) SA 1188 (SCA)

Minister of Forestry $v$ Quathlamba 1973 (3) SA 69 (A)

Minister of Safety and Security $v$ Hamilton 2004 (2) SA 216 (SCA)

Minister of Safety and Security $v$ Rudman 2005 (2) SA 16 (SCA)

Minister of Safety and Security v Van Duivenboden 2002 (6) SA 431 (SCA)

Minister of Safety and Security v Venter 2011 (2) SACR 67 (SCA)

Minister van Polisie v Ewels 1975 (3) SA 590 (A)

Minister van Veiligheid en Sekuriteit v Geldenhuys 2004 (1) SA 515 (SCA)

Oppelt v Head: Health, Department of Health Provincial Administration: Western Cape 2016 (1) SA 325 (CC)

Pro Tempo v Van der Merwe 2018 (1) SA 181 (SCA)

Regal $v$ African Superslate 1963 (1) SA 102 (A)

Silva's Fishing Corporation v Maweza 1957 (2) SA 256 (A)

Soobramoney v Minister of Health, Kwa-Zulu Natal 1998 (1) SA 765 (CC)

South African Hang and Paragliding Association v Bewick 20153 SA 449 (SCA)

Stedall v Aspeling 2018 (2) SA 75 (SCA)

The Head: Health, Department of Health Provincial Administration: Western Cape v Oppelt [2014] ZASCA 135

Tsogo Sun Holdings v Qing-He Shan 2006 (6) SA 537 (SCA)

Van Eeden v Minister of Safety and Security (Women's Legal Centre Trust, as Amicus Curiae) 2003 (1) SA 389 (SCA)

Za v Smith 2015 (4) SA 574 (SCA) 


\section{THE OMISSIONS IN OPPELT}

\section{Legislation}

Bürgerliches Gesetzbuch (1900)

French Code Civil (1804)

Italian Code Civile (1942)

National Health Act 61 of 2003 